\title{
Effect of Bone Marrow Transplantation on Enzyme Levels and Clinical Course in the Neurologically Affected Twitcher Mouse
}

\author{
Peter M. Hoogerbrugge,"* Ben J. H. M. Poorthuis," Ad E. Romme," Jacques J. P. van de Kamp," \\ Gerard Wagemaker," and Dirk W. van Bekkum*s \\ ${ }^{*}$ Department of Pediatrics, Academic Hospital, Leiden, The Netherlands; ${ }^{\ddagger}$ Radiobiological Institute TNO, Rijswijk, \\ The Netherlands; and ${ }^{8}$ Department of Radiobiology, Erasmus University, Rotterdam, The Netherlands
}

\begin{abstract}
The effect of allogeneic bone marrow transplantation (BMT) was investigated in the neurologically affected twitcher mouse, a model for human Krabbe's disease. Twitcher mice have a hereditary deficiency of the lysosomal enzyme galactosylceramidase, which causes growth delay, tremor, and paralysis of the hind legs. Death occurs at 30-40 d of age. After BMT galactosylceramidase activity increased to donor levels in hemopoietic organs. In lung, heart, and liver, galactosylceramidase activity rose to levels intermediate between those of twitcher and normal mice. Increased galactosylceramidase activity in liver parenchymal cells indicated uptake of the donor enzyme by recipient cells of nonhemopoietic origin. Enzyme activity also increased in kidney tissue. BMT resulted in a gradual increase in galactosylceramidase activity in the central nervous system to $15 \%$ of normal donor levels. A 5-6-fold increase in galactosylceramidase activity was found in the peripheral nervous system. This increase in enzyme activity was accompanied by a partial alleviation of neurological symptoms. In particular, paralysis of the hind legs was prevented by BMT. BMT led to a modest restoration of growth and prolonged survival. In several cases, the mice survived for more than $100 \mathrm{~d}$, but eventually all animals died with severe neurological disease.
\end{abstract}

\section{Introduction}

Bone marrow transplantation (BMT) ${ }^{1}$ has been proposed for the treatment of lysosomal storage diseases (1), since bone marrow-derived blood cells and tissue macrophages, which are enzymatically normal, may serve as a continuous source of enzyme. Increased enzyme levels have been reported in plasma, blood cells, and liver tissue after $\operatorname{BMT}(1,2)$. Increased enzyme activity in the central nervous system (CNS) of patients transplanted for lysosomal storage diseases has not been reported. This might be due to the blood-brain barrier, which prevents circulating enzyme from entering the brain tissue (3).

Address all correspondence to Dr. P. M. Hoogerbrugge, Radiobiological Institute TNO, P. O. Box 5815, 2280 HV Rijswijk, The Netherlands.

Received for publication 7 May 1987 and in revised form 29 October 1987.

1. Abbreviations used in this paper: BMT, bone marrow transplantation; CNS, central nervous system; PNS, peripheral nervous system.

J. Clin. Invest.

(c) The American Society for Clinical Investigation, Inc.

0021-9738/88/06/1790/05 \$2.00

Volume 81, June 1988, 1790-1794
Evidence that BMT has a beneficial effect on the neurological symptoms of patients with lysosomal storage diseases is inconclusive so far.

Since evaluation of the effect of BMT in patients is complicated by the variability in clinical course (4), inbred strains of mutant mice, which show a uniform disease pattern, are important tools with which to study the effects of BMT.

The twitcher mouse is a mutant with a hereditary deficiency of the lysosomal enzyme galactosylceramidase, which results in severe lesions of the CNS (5). This deficiency results in a disease pattern similar to human globoid cell leukodystrophy (Krabbe's disease) (6). Galactosylceramidase plays an important role in the turnover of myelin (5). The pathological lesions of the CNS, e.g., severe demyelination, disappearance of oligodendrocytes, and globoid cell infiltration, are similar to those described for the human disease. In comparison to the human disease, peripheral nervous system (PNS) involvement is prominent in twitcher mice (6). In the present investigation, galactosylceramidase levels in CNS and other tissues and the clinical course of the disease were recorded in twitcher mice after BMT.

\section{Methods}

Mice. The original stock of twitcher mice was obtained from Jackson Laboratory, (Bar Harbor, ME) and has been mated on a C57BL-6J background for $\sim 12$ generations. A colony of twitcher mice has been maintained in our laboratory by brother-sister matings using heterozygous mice. Affected mice were identified by the galactosylceramidase activity in clipped tails (7) at day 3-5 after birth as described in detail in Enzyme assays.

Enzymatically normal male and female, congenic C57BL-6J mice, 8-10 wk old, were used as bone marrow donors.

Bone marrow transplantation. Bone marrow was obtained by flushing tibiae and femora of donor mice with Hepes' buffered HBSS. Twitcher mice and normal control littermates were irradiated at 8-11 $\mathrm{d}$ of age with a lethal whole body dose $(9.0 \mathrm{~Gy})$ of ${ }^{137} \mathrm{Cs}$ gamma rays. $1 \mathrm{~d}$ later, the mice were transplanted intraperitoneally with $3-5 \times 10^{7}$ bone marrow cells using $30 \mathrm{G}$ needles. After weaning, the mice were fed standard laboratory animal chow soaked in acidified water, placed on the floor of the cage to facilitate feeding. No further supportive care was given.

Isolation of liver parenchymal cells. Liver parenchymal cells were isolated by collagenase treatment as described by van Bezooyen et al. (8), with minor modifications to make this method applicable to twitcher mice weighing only 6-7 g. Briefly, the livers of the transplanted mice and controls were perfused in situ through the portal vein with $\mathrm{Ca}^{++}$-free perfusion medium (8), followed by $0.05 \%$ collagenase in perfusion medium for $20 \mathrm{~min}$ at $37^{\circ} \mathrm{C}$ with a flow rate of 0.7 $\mathrm{ml} / \mathrm{min}$. Immediately after perfusion, the liver was removed and minced finely. After sieving, the cell suspension was centrifuged for $1-3 \mathrm{~min}$ at $30 \mathrm{~g}$. The pellet consisted of $>95 \%$ liver parenchymal cells. The viability of these cells as measured with trypan blue exclusion was $>90 \%$. 
Table I. Galactosylceramidase Levels (nmol $h^{-1}$ per $\mathrm{mg}_{\text {Protein }}{ }^{-1}$; Mean \pm SD) in Various Organs of Untreated Twitcher Mice, Untreated C57BL-6J Control Mice, and Transplanted Twitcher Mice of Various Ages

\begin{tabular}{|c|c|c|c|c|c|c|}
\hline & \multicolumn{2}{|c|}{ Untreated mice } & \multicolumn{4}{|c|}{ Transplanted twitcher mice } \\
\hline & C57BL-6J & Twitcher & & & & \\
\hline $\begin{array}{l}\text { Age (d) ... } \\
\text { No. of mice... }\end{array}$ & $\begin{array}{c}30-80 \\
3\end{array}$ & $\begin{array}{c}25-35 \\
7\end{array}$ & $\begin{array}{r}25 \\
2\end{array}$ & $\begin{array}{r}50 \\
3\end{array}$ & $\begin{array}{r}80 \\
2\end{array}$ & $\begin{array}{r}100 \\
3\end{array}$ \\
\hline Bone marrow & $4.8 \pm 0.4$ & $0.13 \pm 0.04$ & $4.7 ; 7.4$ & $4.9 \pm 1.9$ & $6.0 ; 7.1$ & $7.0 \pm 0.7$ \\
\hline Spleen & $5.4 \pm 0.5$ & $0.12 \pm 0.04$ & $3.8 ; 5.0$ & $5.7 \pm 1.4$ & $2.5 ; 3.7$ & $3.0 \pm 0.8$ \\
\hline Liver & $2.7 \pm 1.0^{*}$ & $0.08 \pm 0.02$ & $1.03 ; 1.13$ & $0.98 \pm 0.31$ & $1.03 ; 1.24$ & $0.79 \pm 0.06$ \\
\hline Lung & $3.5 \pm 0.4$ & $0.04 \pm 0.01$ & $0.49 ; 0.50$ & $0.46 \pm 0.11$ & $0.32 ; 0.47$ & $0.42 \pm 0.08$ \\
\hline Kidney & $18.8 \pm 1.7$ & $0.07 \pm 0.01$ & $0.23 ; 0.27$ & $0.23 \pm 0.13$ & $0.18 ; 0.20$ & $0.30 \pm 0.04$ \\
\hline Heart & $0.5 \pm 0.1$ & $0.03 \pm 0.01$ & $0.14 ; 0.19$ & $0.10 \pm 0.01$ & $0.11 ; 0.12$ & $0.14 \pm 0.01$ \\
\hline CNS & $1.7 \pm 0.2^{\ddagger}$ & $0.06 \pm 0.01$ & $0.07 ; 0.09$ & $0.17 \pm 0.05$ & $0.19 ; 0.40$ & $0.26 \pm 0.01$ \\
\hline PNS & $3.5 \pm 0.7$ & $0.10 \pm 0.08^{\S}$ & ND & ND & ND & $0.57 \pm 0.15$ \\
\hline Liver parenchymal cells & $2.2 \pm 0.2$ & $0.11 \pm 0.01^{\S}$ & ND & ND & $0.49 ; 0.39$ & ND \\
\hline
\end{tabular}

${ }^{*} n=11,{ }^{\ddagger} n=7,{ }^{\&} n=3, \quad \mathrm{ND}$, not determined.

Enzyme assays. Animals were perfused with saline to remove contaminating blood before dissection of the organs. After dissection, the organs were quickly frozen and stored at $-80^{\circ} \mathrm{C}$. A $10-20 \%$ homogenate in water was prepared. After appropriate dilution with water, homogenates were briefly sonicated. Protein was determined by the method of Lowry (9). ${ }^{3} \mathrm{H}$-Labeled galactosylceramide $30,900 \mathrm{dpm} /$ nmol sp act) was prepared from nonhydroxy fatty acid cerebrosides from brain tissue (Sigma Chemical Co., St. Louis, MO) as described by Suzuki (10). The assay conditions were similar to those described by Svennerholm et al. (11). Briefly, the incubation mixture $(50 \mu \mathrm{l})$ contained $12.5 \mathrm{nmol}{ }^{3} \mathrm{H}$-galactosylceramide, $300 \mu \mathrm{g} \mathrm{Na-taurocholate,} 15$ $\mu$ g oleic acid, $10 \mu 10.25 \mathrm{M} \mathrm{Na}$-acetate buffer ( $\mathrm{pH} 4.2$ ), and a maximum of $40 \mu \mathrm{g}$ protein. The incubation was performed at $37^{\circ} \mathrm{C}$ for $2 \mathrm{~h}$. Under these conditions, the enzyme activity was linear with time and the amount of protein except for PNS homogenates. Galactosylceramidase activity in this tissue was determined after delipidation with 1 vol of ice-cold $N$-butanol to ensure linearity with the amount of homogenate added. Specific activities of galactosylceramidase in PNS are expressed relative to the amount of protein present in the homogenate before delipidation. After incubation, the reaction mixture was extracted (12) and part of the upper phase counted in a liquid scintillation counter.

Ganglioside-beta-galactosidase and total $N$-acetyl-beta-D-glucosaminidase (hexosaminidase) were measured with standard fluorimetric assays as described (13).

The specificity of the galactosylceramidase assay was further tested as follows: brain and kidney homogenates of normal, transplanted twitcher, and untreated twitcher mice were preincubated with and without beta-D-galactopyranosyl-methyl-p-nitrophenyl-triazene, (a generous gift of Dr. O. P. van Diggelen, Department of Clinical Genetics, Erasmus University, Rotterdam, The Netherlands). In the presence of a 5-mM citrate/phosphate buffer ( $\mathrm{pH}$ 6.0), beta-D-galactopyranosyl-methyl-p-nitrophenyl-triazene is a specific inhibitor of ganglioside-beta-galactosidase (14), and preincubation with $0.1 \mathrm{mM}$ of this compound led to virtually complete inhibition of ganglioside-beta-galactosidase activity. The residual activity was $4 \%$ in kidney and $1 \%$ in brain tissue. Under these conditions, the galactosylceramidase activity was unaffected, indicating that the small residual activities of galactosylceramidase measured in twitcher mice were not due to gangliosidebeta-galactosidase.

With the galactosylceramidase assay described above, affected mice could be easily identified by the enzyme activity in clipped tails (7). Affected mice had low galactosylceramidase activity $(0.15 \pm 0.03$; mean $\pm S D)$ as compared with heterozygous $(1.79 \pm 0.15)$ and homozygous normal mice $\left(3.31 \pm 0.39 \mathrm{nmol} / \mathrm{h}^{-1}\right.$ per mg protein $\left.{ }^{-1}\right)$.
Enzyme activity was determined in bone marrow cells, spleen, kidney, liver, lung, heart, plasma, PNS, and CNS. The sciatic nerves were used to determine galactocylceramidase in the PNS.

Functional testing of gross motoric ability. Gross locomotor testing was performed according to the method described by Altman and Sudarshan (15). Briefly, the mice were placed with their heads downward on a surface covered with a layer of cotton which was positioned under variable angles of $30-80^{\circ}$. All the normal mice made a $180^{\circ}$ turn, even at angles of $80^{\circ}$, and climbed the surface. The ability to do this was tested in untreated and transplanted twitcher mice.

Statistical analysis. The $t$ test was used for statistical analysis of the enzyme levels. Differences observed were considered to be significant at $P$ values $<0.01$. The probability of survival was estimated according to Kaplan and Meier (16), with censoring of the mice that were killed to obtain organ specimens for analysis.

\section{Results}

Galactosylceramidase activities in transplanted mice and controls. As shown in Table I, twitcher mice were severely lacking galactosylceramidase in all organs tested. The enzyme activity in plasma was below detection level.

After BMT, galactosylceramidase activity in the hemopoietic organs (spleen and bone marrow) increased to levels that were similar to those of untransplanted C57BL-6J mice of the same age, which served as controls. In the liver, lungs, and heart, the enzyme activity increased significantly to levels intermediate between those of untreated twitchers and controls. In addition to whole liver, we determined galactosylceramide activity in liver parenchymal cells of normal mice, untreated twitcher mice, and twitcher mice that received BMT. The results showed a significant increase in the liver parenchymal cells of transplanted twitcher mice as compared with those of untreated twitcher mice (Table I). ${ }^{2}$

2. To evaluate the possible contribution of small amounts $(<5 \%)$ of contaminating nonparenchymal cells to the galactosylceramidase activity in liver parenchymal cell preparations we determined the specific activity $(6.2 \pm 3.1 \mathrm{nmol} / \mathrm{h}$ per $\mathrm{mg}$ protein) and protein content $\left(0.04 \pm 0.01 \mathrm{mg} / 10^{6}\right.$ cells $)$ of nonparenchymal cells of control mice. The protein content of parenchymal cells $\left(2.4 \pm 1.0 \mathrm{mg} / 10^{6}\right.$ cells $)$ was $\sim 60$ times higher. Therefore, a maximum of $5 \%$ contaminating nonparenchymal cells would contribute for $0.0054 \mathrm{nmol} / \mathrm{h}$ per $\mathrm{mg}$ protein to the specific activity found in the parenchymal cell fraction. 
In kidney tissue, a minor but statistically significant increase in enzyme activity, from 0.3 to $1.6 \%$ of control levels, was demonstrated.

Remarkably, a gradual rise in galactosylceramidase activity occurred after BMT in the CNS of twitcher mice, to $15 \%$ of the enzyme levels of unaffected controls.

The increase in galactosylceramidase activity in most organs was already evident in 25 -d-old mice. The enzyme levels hardly increased any further during the lifespan of the transplanted animals (Table I), except in the CNS, in which a steady increase occurred between 25 and $100 \mathrm{~d}$.

The specific activities of the control enzyme gangliosidebeta-galactosidase in liver, kidney, and CNS of untreated twitcher mice, transplanted twitcher mice, and untreated controls were not statistically different (Table II). The transplanted and untreated twitcher mice had significantly higher levels of total hexosaminidase, another control enzyme, than did untreated C57BL-6J controls. Significant differences in hexosaminidase activity between transplanted and untreated twitcher mice were not observed (Table II).

Clinical syndrome. In homozygous twitcher mice that were apparently normal at birth, growth delay was apparent when the mice were $\sim 3 \mathrm{wk}$ old. Severe tremor, especially of the head, occurred at $\sim 4$ wk. During the later stages of the disease, the hind legs became paralyzed and the mice died at $34 \pm 4 \mathrm{~d}$ of age (mean $\pm \mathrm{SD}$ ); none of the mice survived longer than 41 d. After BMT, the lifespan was prolonged (Fig. 1), with a probability of survival at day 100 of $36 \%$. Approximately $20 \%$ of the mice, both twitchers and controls, died within $20 \mathrm{~d}$ after BMT due to the transplant procedure per se, e.g., severe hemorrhage. If these early deaths had been censored in the Kaplan-Meier analysis, the probability of survival at day 100 would increase to $48 \%$.

After BMT, the transplanted twitchers and the transplanted controls temporarily lost body weight as compared with the untreated mice. The weight of the transplanted twitcher mice increased to levels that were significantly higher at day 100 than those of untreated twitchers $(9.9 \pm 1.6 \mathrm{~g}$ vs. $8.1 \pm 0.8 \mathrm{~g}, P<0.05)$, but remained much below those of normal mice (Fig. 2) and of transplanted controls (13.1 \pm 0.7 at day 70 after BMT).

The head tremor was still evident after BMT. All transplanted mice tested at day $100(n=3)$ were able to turn around

Table II. Levels (nmol/ $\mathrm{h}^{-1}$ per $\mathrm{mg}_{\text {protein }}{ }^{-1}$; Mean \pm SD) of Ganglioside-Beta Galactosidase and Hexosaminidase $A$ and $B$ in Various Organs of Transplanted Twitcher Mice, Untreated Twitcher Mice, and Untreated Normal Control Mice

\begin{tabular}{lccc}
\hline & $\begin{array}{c}\text { Transplanted } \\
\text { twitcher mice }\end{array}$ & $\begin{array}{c}\text { Untreated } \\
\text { twitcher mice }\end{array}$ & $\begin{array}{c}\text { Untreated } \\
\text { normal controls }\end{array}$ \\
\hline No. of mice ... & 2 & 2 & 3 \\
Kidney* & $354 \pm 78$ & $362 \pm 30$ & $366 \pm 26$ \\
Liver* $^{*}$ & $159 \pm 1$ & $142 \pm 28$ & $152 \pm 3$ \\
CNS $^{*}$ & $75 \pm 4$ & $88 \pm 16$ & $108 \pm 5$ \\
Kidney $^{*}$ & $2295 \pm 13$ & $1793 \pm 128$ & $1487 \pm 124$ \\
Liver & $1964 \pm 21$ & $1923 \pm 494$ & $992 \pm 91$ \\
CNS $^{\ddagger}$ & $3520 \pm 127$ & $3810 \pm 738$ & $1114 \pm 42$ \\
\hline
\end{tabular}

* Ganglioside-beta galactosidase.

${ }^{\ddagger}$ Hexosaminidase $\mathrm{A}$ and $\mathrm{B}$.

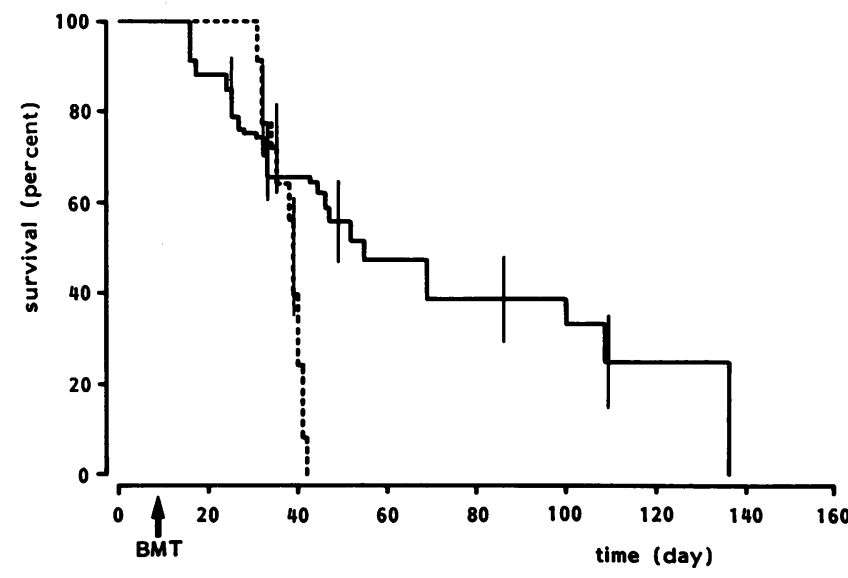

Figure 1. Survival (Kaplan-Meier plots) of transplanted $(-, n$ $=33)$ and untreated $(---, n=30)$ twitcher mice.

and climb a $80^{\circ}$ angle, in contrast to untreated, 35-d-old twitcher mice that failed in these tests, already at an angle of $30^{\circ}(n=7)$.

\section{Discussion}

The results of our studies demonstrate that BMT in twitcher mice results in increased galactosylceramidase activity in all organs tested.

The observation that galactosylceramidase levels in spleen and bone marrow increased after BMT to levels of normal donor mice demonstrates that stable radiation chimeras were obtained with our transplant procedure.

In lung tissue, enzyme activity increased to $14 \%$ of control levels. In this tissue, the alveolar macrophages are replaced by donor-derived cells after BMT (17). It cannot be concluded from the present data whether such a replacement can account completely for the increase of galactosylceramidase activity, or whether transfer of enzyme to other cell types in the lungs has also occurred.

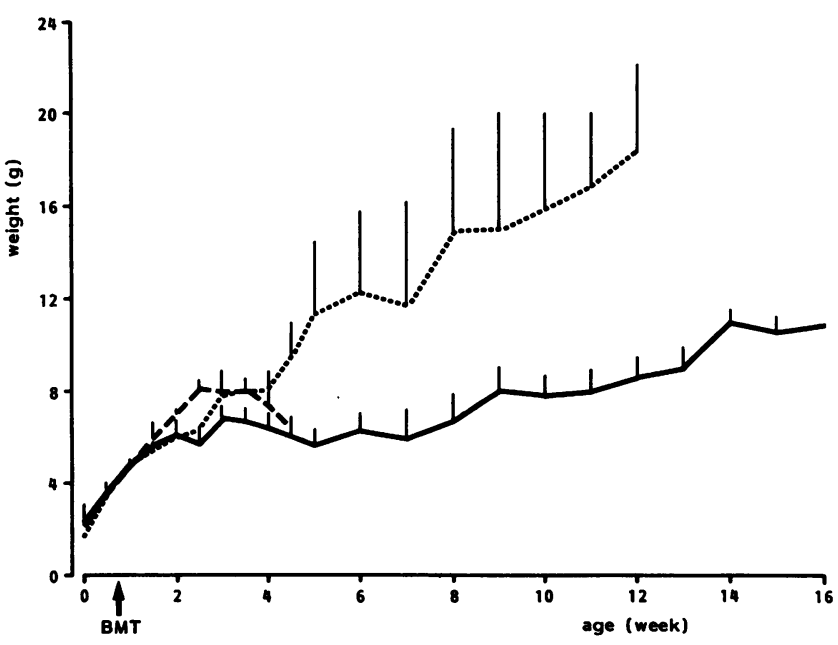

Figure 2. Weight of transplanted twitcher mice (-), untreated twitcher mice (-- $)$, and untreated controls $(\cdots)$. 5-12 mice were used for each data point. 
The galactosylceramidase activity in liver tissue increased to $36 \%$ of the control levels. This increase compares well with data from other studies in animal models $(13,18-20)$ and in patients $(2,21)$. After BMT, Kupffer cells are replaced by donor-derived macrophages (22), although it is not fully known how fast this replacement occurs. Our studies have shown that the increased enzyme activity in liver tissue of transplanted twitcher mice is not due only to Kupffer cell replacement, but also to uptake of galactosylceramidase by liver parenchymal cells, as the galactosylceramidase activity in isolated liver parenchymal cells increased after BMT from 5 to $16 \%$ of the activity found in donor mice. This increase could not be explained by contamination with donor-derived cells. ${ }^{2}$ We have reported a similar transfer of enzyme in the beta-glucuronidase-deficient mouse (23). These observations show that certain lysosomal enzymes that originate from hemopoietic cells can be taken up by another cell type.

Our studies demonstrate a significantly increased enzyme activity in the heart and kidneys of transplanted twitcher mice, although the activity in the kidney was still only $1-2 \%$ of control values. Normal kidney tissue had the highest specific galactosylceramidase activity of all organs tested. In kidneys of untreated twitcher mice, accumulation of galactosylceramide has been reported $(24,25)$. It is not known whether the fourfold increase in galactosylceramidase in kidney tissue after BMT has any effect on the levels of galactosylceramide in this tissue. As the presence of tissue macrophages in kidneys is questionable (26-28), the mechanism of this increase is not known. With respect to the increased enzyme activity in heart tissue, it is interesting to compare our data with the improved cardiac function reported in a patient with Maroteaux-Lamy syndrome (2).

The activities of the two control enzymes, hexosaminidase and ganglioside-beta-galactosidase, did not increase in transplanted twitcher mice as compared with untreated twitcher mice. This indicates that the increase in galactosylceramidase levels after BMT is not due to nonspecific side effects of the transplantation procedure. The hexosaminidase activity in untreated as well as transplanted twitcher was significantly higher than in untreated normal controls. This may be explained by the observation that the number and size of lysosomes often increase in lysosomal storage diseases, which results in higher activities of the unaffected enzymes (29).

The observed improvement of hind leg paralysis after BMT indicates a beneficial effect of BMT on lesions in the PNS. This correlates well with the increased galactosylceramidase activities in 100-d-old transplanted twitcher mice. Yeager et al. reported histopathological (30) and electrophysiological (31) improvement of PNS lesions, but no improvement of the morphological and functional deterioration of the CNS.

One of the major problems in the treatment of lysosomal storage diseases by BMT is the inaccessibility of the CNS for cells and circulating enzyme. Circulating enzyme cannot enter the brain tissue due to the blood-brain barrier, and circulating cells only enter the brain after trauma and infection (32). It is not known whether donor-derived cells enter brain tissue after BMT. Bartlett's claims (33) that mice brain tissue contains substantial numbers of hemopoietic stem cells have been disproved by our group (34). In most bone marrow recipients suffering from a type of lysosomal storage disease with severe involvement of the CNS (e.g., Sanfilippo-A disease [35] and Hunter's syndrome [36]), improvement of the neurological symptoms has not been conclusively reported. Only in two patients with metachromatic leukodystrophy, a possible beneficial effect of BMT was reported $(37,38)$. A longer follow-up period perhaps is needed for final conclusions, as the natural course of this disease is variable (39).

In this study, galactosylceramidase activity increased significantly to $14-16 \%$ of controls in the CNS of 50-100-d-old, transplanted twitcher mice. In most animal model studies reported, increased enzyme activities in the CNS were not seen after BMT $(13,18)$. Only in a biopsy specimen of a mucopolysaccharidosis I dog (40) and in autopsy material of a fucosidosis dog (20), have increased enzyme activities after BMT been reported. In both studies, contamination with blood cannot be completely ruled out.

Infiltration of globoid cells in the CNS occurs in twitcher mice. It has been suggested that these cells are derived from blood monocytes (41). This indicates that infiltration of macrophages might explain the increased enzyme activity in the CNS of transplanted twitcher mice. It is interesting to compare these data with those obtained in another mutant mouse, the beta-glucuronidase-deficient $\mathrm{C} 3 \mathrm{H}$ mouse (13). In this mouse model, lesions in the CNS are not present, and, therefore, infiltration of macrophages is less likely. In the beta-glucuronidase-deficient mouse, an increase in enzyme activity in the CNS was not found after BMT. Despite the significantly increased galactosylceramidase activity in the CNS of transplanted twitcher mice, the tremor is not alleviated after BMT, which suggests that either the galactosylceramidase does not enter the oligodendrocytes (the target cells in Krabbe's disease), or that the lesions are already irreversible at the time of BMT. With respect to the latter possibility, it is important to note that myelination in mice is most active between day 5 and 30 after birth (42), which is before the galactosylceramidase levels in the CNS start to increase in transplanted twitcher mice.

\section{Acknowledgments}

This research was supported by grant No. 28-1021 from "Praeventie Fonds," The Netherlands. The authors wish to express their gratitude to Mr. J. I. M. van Hooft, head of biotechnical services, for breeding the twitcher mice. We gratefully acknowledge Dr. K. Suzuki, Department of Biological Sciences, University of North Carolina School of Medicine, for his critical reading of the manuscript.

\section{References}

1. Hobbs, J. R., A. J. Barrett, D. Chambers, D. C. O. James, K. Hugh-Jones, N. Byrom, K. Henry, C. F. Lucas, T. R. Rogers, P. F. Benson, L. R. Tansley, A. D. Patrick, J. Mossman, and E. P. Young. 1981. Reversal of clinical features and biochemical improvement after treatment by bone marrow transplantation. Lancet. ii:709-712.

2. Krivit, W., M. E. Pierpont, K. Ayaz, M. Tsai, N. K. C. Ramsay, J. H. Kersey, S. Weisdorf, R. Sibley, D. Snover, M. M. McGovern, M. F. Schwartz, and R. J. Desnick. 1984. Bone marrow transplantation in the Maroteaux-Lamy syndrome (Mucopoly-saccharidosis VI). N. Engl. J. Med. 311:1606-1611.

3. Neuwelt, E. A., J. A. Barranger, R. O. Brady, M. Pagel, F. S. Furbish, J. M. Quirk, G. F. Mook, and E. Frenkel. 1981. Delivery of hexosaminidase $A$ to the cerebrum after osmotic modification of the blood-brain barrier. Proc. Natl. Acad. Sci. USA. 78:5838-5841.

4. Zlotogora, J., and G. Bach. 1986. Pseudodeficiencies in lysosomal storage disorders. Lancet. ii. 1296. (Abstr.)

5. Kobayashi, T., T. Yamanaka, J. M. Jacobs, F. Teixeira, and K. Suzuki. 1980. The twitcher mouse: an enzymatically authentic model 
of human globoid cell leukodystrophy (Krabbe's disease). Brain Res. 202:479-483.

6. Duchen, L. W., E. M. Eicher, J. M. Jacobs, F. Scaravilli, and F. Teixeira. 1980. Hereditary leukodystrophy in the mouse: the new mutant twitcher. Brain. 103:695-710.

7. Kobayashi, T., H. Nagara, K. Suzuki, and K. Suzuki. 1982. The twitcher mouse: determination of genetic status by galactosylceramidase assays on clipped tail. Biochem. Med. 27:8-14.

8. Van Bezooijen, C. F. A., T. Grell, and D. L. Knook. 1977. The effect of age on protein synthesis by isolated liver parenchymal cells. Mech. Ageing Dev. 6:293-304.

9. Lowry, O. H., N. J. Rosenbrough, A. L. Farr, and R. J. Randall. 1951. Protein measurement with the Folin phenol reagent. J. Biol. Chem. 193:265-275.

10. Suzuki, K. 1977. Globoid cell leukodustrophy (Krabbe disease) and GM1-gangliosidosis. In Practical Enzymology of the Sphingolipidoses. R. H. Glew and S. P. Peters, editors. Alan R. Liss, Inc., New York. 101-136.

11. Svennerholm, L., M. T. Vanier, G. Hakansson, and J. E. Mansson. 1981. Use of leukocytes in diagnosis of Krabbe disease and detection of carriers. Clin. Chim. Acta. 112:333-340.

12. Wenger, D. A., M. Sattler, and S. P. Markey. 1973. Deficiency of monogalactosyl diglyceride beta-galactosidase activity in Krabbe's disease. Biochem. Biophys. Res. Commun. 53:680-684.

13. Hoogerbrugge, P. M., B. J. H. M. Poorthuis, A. H. Mulder, G. Wagemaker, L. J. Dooren, J. M. J. J. Vossen, and D. W. van Bekkum. 1987. Correction of lysosomal enzyme deficiency in various organs of beta-glucuronidase deficient mice by bone marrow transplantation. Transplantation (Baltimore). 43:609-614.

14. van Diggelen, O. P., H. Galjaard, M. L. Sminott, and P. J. Smith. 1980. Specific inactivation of lysosomal glycosidases in living fibroblasts by the corresponding glycosyl-methyl-p-nitrophenyl-triazenes. Biochem. J. 188:337-343.

15. Altman, J., and K. Sudarshan. 1975. Postnatal development of locomotion in the laboratory rat. Anim. Behav. 23:896-920.

16. Kaplan, E. L., and P. Meier. 1958. Nonparametric estimation from incomplete observations. J. Am. Statist. Assoc. 53:457-481.

17. Thomas, E. D., R. E. Ramberg, G. E. Sale, R. S. Sparkes, and D. W. Golde. 1976. Direct evidence for a bone marrow origin of the alveolar macrophage in man. Science (Wash. DC). 192:1016-1018.

18. Wenger, D. A., P. W. Gasper, M. A. Thrall, S. M. Dial, R. A. LeCouteur, and E. A. Hoover. 1986. Bone marrow transplantation in the feline model of arylsufatase-B deficiency. In Bone Marrow Transplantation for Treatment of Lysosomal Storage Diseases. W. Krivit and N. W. Paul, editors. March of Dimes Birth Defects Foundation Original Article Series. Alan R. Liss, Inc., New York. 22:177-186.

19. Slavin, S., and S. Yatziv. 1980. Correction of enzyme deficiency by allogeneic bone marrow transplantation with total lymphoid irradiation. Science (Wash. DC). 210:1150-1152.

20. Taylor, R. M., B. R. H. Farrow, G. J. Stewart, and P. J. Healy. 1976. Enzyme replacement in nervous tissue after allogeneic bone marrow transplantation for fucosidosis in dogs. Lancet. ii:772-774.

21. Whitley, C. B., N. K. C. Ramsay, J. H. Kersey, and W. Krivit. 1986. Bone marrow transplantation for Hurler syndrome: assessment of metabolic correction. In Bone Marrow Transplantation for Treatment of Lysosomal Storage Diseases. W. Krivit and N. W. Paul, editors. March of Dimes Birth Defects Foundation Original Article Series. Alan R. Liss, Inc., New York. 22:7-24.

22. Gale, R. P., R. S. Sparks, and D. W. Golde. 1978. Bone marrow origin of hepatic macrophages (Kuppfer cells) in humans. Science (Wash. DC). 192:1016-1018.

23. Hoogerbrugge, P. M., B. J. H. M. Poorthuis, G. Wagemaker, and D. W. van Bekkum. 1986. Bone marrow transplantation in lysosomal enzyme deficiency: increased enzyme activity in lysosomes of recipient cells. Exp. Hematol (NY). 14:553. (Abstr.)

24. Igisu, H., H. Takahashi, K. Suzuki, and K. Suzuki. 1983. Abnormal accumulation of galactosylceramide in the kidney of twitcher mouse. Biochem. Biophys. Res. Commun. 110:940-944.
25. Takahashi, H., H. Igisu, K. Suzuki, and K. Suzuki. 1984. Murine globoid cell leukodystrophy: the twitcher mouse (an ultrastructural study of the kidney). Lab. Invest. 50:42-50.

26. Raftery, M. J., L. W. Poulter, P. Sweny, O. N. Fernando, G. Janossy, and J. F. Moorhead. 1983. Heterogeneity of macrophage-like cells in normal kidney and renal allograft rejection. Transplant Proc. 15:1781-1783.

27. Alpers, C. E., and J. H. Beckstead. 1985. Monocyte/macrophage derived cells in normal and transplanted human kidneys. Clin. Immunol. Immunopathol. 36:129-140.

28. Marshall, R. J., and A. G. Maciver. 1984. The monocyte/macrophage population of the normal human kidney. J. Pathol. 143:275280.

29. Hers, H. G. The concept of inborn lysosomal disease. 1973. In Lysosomes and Lysosomal Storage Diseases. H. G. Hers and F. van Hoof, editors. Academic Press, Inc., New York. 148-164.

30. Yeager, A. M., S. Brennan, C. Tiffany, H. W. Moser, and G. W. Santos. 1984. Prolonged survival and remyelination after hemopoietic cell transplantation in the twitcher mouse. Science (Wash. DC). 225:1052-1054.

31. Toyoshima, E., A. M. Yeager, S. Brennan, G. W. Santos, H. W. Moser, and R. F. Mayer. 1986. Nerve conduction studies in the twitcher mouse (murine globoid cell leukodystrophy). J. Neurol. Sci. 74:307-318.

32. Fujita, S., and T. Kitamura. 1975. Origin of brain macrophages and the nature of the so-called microglia. Acta Neuropathol. Suppl. 6:291-298.

33. Bartlett, P. F. 1982. Pluripotential hemopoietic stem cells in adult mouse brain. Proc. Natl. Acad. Sci. USA. 79:2722-2725.

34. Hoogerbrugge, P. M., G. Wagemaker, and D. W. van Bekkum. 1985. Failure to demonstrate pluripotential hemopoietic stem cells in mouse brains. Proc. Natl. Acad. Sci. USA. 82:4268-4287.

35. Hugh-Jones, K., J. R. Hobbs, C. Pot, P. J. Shaw, S. Williamson, and M. Knapp. 1986. Comparison of serial psychomotor testing of children with various mucopolysaccharidoses following bone marrow transplantation. Bone Marrow Transplant. 1(Suppl.):342. (Abstr.)

36. Warkentin, P. I., M. S. Dixon, I. Schafer, S. E. Strandjord, and P. F. Coccia. 1986. Bone marrow transplantation in Hunter Syndrome: A preliminary report. In Bone Marrow Transplantation for Treatment of Lysosomal Storage Diseases. W. Krivit and N. W. Paul, editors. March of Dimes Birth Defects Foundation Original Article Series. Alan R. Liss, Inc., New York. 22:31-39.

37. Bayever, E., S. Ladisch, N. Brill, M. Nuwer, R. S. Sparkes, and S. A. Feig. 1985. Bone marrow transplantation for metachromatic leucodystrophy. Lancet. ii:471-473.

38. Lipton, M. E., L. A. Lockman, N. K. C. Ramsay, J. H. Kersey, R. I. Jacobson, and W. Krivit. 1986. Bone marrow transplantation in metachromatic leukodystrophy. In Bone Marrow Transplantation for Treatment of Lysosomal Storage Diseases. W. Krivit and N. W. Paul, editors. March of Dimes Birth Defects Foundation Original Article Series. Alan R. Liss, Inc., New York. 22:57-67.

39. Kolodny, E. H., and H. W. Moser. 1983. Sulfatide lipidosis: metachromatic leukodystrophy. In The Metabolic Basis of Inherited Disease. 5th ed. J. B. Stanbury, J. B. Wyngaarden, D. S. Fredrickson, J. L. Goldstein, and M. S. Brown, editors. McGraw-Hill Book Co., New York. 881-905.

40. Shull, R. M., N. E. Hastings, R. R. Selcer, J. B. Jones, J. R. Smith, W. C. Cullen, and G. C. Constantopoulos. 1987. Bone marrow transplantation in canine mucopolysaccharidosis. I. Effects within the central nervous system. J. Clin. Invest. 79:435-443.

41. Suzuki, K., and K. Suzuki. 1983. Galactosylceramide lipidosis: globoid cell leukodystrophy (Krabbe's disease). In The Metabolic Basis of Inherited Disease. 5th ed. J. B. Stanbury, J. B. Wyngaarden, D. S. Fredrickson, J. L. Goldstein, and M. S. Brown, editors. McGraw-Hill Book Co., New York. 857-880.

42. Constantino-Ceccarini, E., and P. Morell. 1972. Biosynthesis of brain sphingolipids and myelin accumulation in the mouse. Lipids. 7:656-659. 